Agro-Science Journal of Tropical Agriculture, Food, Environment and Extension Volume 15 Number 1 January, 2016 pp. 11-16

ISSN 1119-7455

\title{
UTILIZATION POTENTIALS OF LABLAB (Lablab purpureus (L.) Sweet) AND THE CONSTRAINTS OF FIELD PESTS AND DISEASES IN NIGERIA
}

\author{
Ewansiha*, S.U., Ogedegbe, S.A. and Falodun, E.J. \\ Department of Crop Science, Faculty of Agriculture, University of Benin, Benin City, Nigeria \\ *Corresponding author's email: sylvester.ewansiha@uniben.edu; Tel.: +2348056351478
}

\begin{abstract}
In the last one decade and half, lablab was evaluated for its crop-livestock production potentials in Samaru, Kano and Benin City in both the savanna and humid forest zones of Nigeria. Very early, early and intermediate accessions were identified that may be suitable for dry savanna and late growing season of the humid forest while late, very late and extremely late accessions were identified for moist savanna and humid forest. Vegetable-type, grain-type and dual-purpose lablab were identified. Lablab grain ranged from 600-2400 $\mathrm{kg} \mathrm{ha}^{-1}$ with an average protein concentration of $25.3 \%$. Huge litter of leaves and stems was recorded at the end of production period which extended far into the dry season. Short fallow of one year supported maize-cowpea intercrop with component maize having $13.7 \%$ grain yields over that of natural fallow. Following a 2-year lablab fallow, subsequent maize yield was $72.7 \%$ higher than that from natural fallow. Lablab had an average of $2600 \mathrm{~kg} \mathrm{ha}-1$ of biomass and an average of $64.1 \mathrm{~kg} \mathrm{~N} \mathrm{ha}^{-1}$, meaning that lablab has high potential for green manure and soil improvement. Of six herbaceous legumes, lablab was among those that had the highest soil cover. Fresh biomass of $3200 \mathrm{~kg} \mathrm{ha}^{-1}$ was achieved at eight weeks after planting. Various insect pests, fungal diseases and parasitic plant including Ootheca mutabilis (Sahlb), Podagrica uniforma (Jac.), Nematocerus acerbus (Faust), Anoplocnemis curvipes (F.), Helicoverpa armigera (Hbn), aphids, Colletotrichum sp., Curvularia sp. and Cassytha filiformis (Linn.) were found on lablab plants, causing damage to the crop.
\end{abstract}

Key words: lablab, fodder, grain yield, pest, disease

\section{INTRODUCTION}

Lablab purpureus (L.) Sweet syn. Dolichos lablab L., Lablab niger medik commonly known as lablab or hyacinth bean is extremely diverse and remarkably adaptable with its various genotypes thriving in different areas and under diverse conditions including arid, semi-arid and humid regions (NAS, 1979; Duke et al., 1981). It is an underutilized but a multipurpose crop used for food, forage, soil improvement, soil protection and weed control (Schaaffhausen, 1963; Grubben, 1977; Kay, 1979; NAS, 1979; Wood, 1983; Yamaguchi, 1983; Shivashankar et al., 1993).

Crop and livestock production are major agricultural enterprises in Nigeria, contributing to household welfare and national economy (Kowal and Kassam, 1978; Ndubuisi et al., 1998). However, in the Nigerian savanna, most soils are naturally of low fertility and the amount of organic nitrogen mineralized annually is often well below the requirement for high crop yields. Due to human population and economic pressures, fallow has been shortened or has entirely disappeared (Kowal and Kassam, 1978; Manyong et al., 1997). This has resulted in continuous cropping or land-use intensification which, in turn, are causing serious soil degradation/erosion and fertility problems, decline in natural species diversity and crop yield, weed problems (Kowal and Kassam, 1978; Webster and Wilson, 1980; Ehui and Jabbar in Jagtap and Amissah-Arthur, 1999; Jabbar, 1995; Tian et al., 1995; Anon, 1997a). In the humid forest of Nigeria, land use has also intensified. There are soil fertility problems and crop yields are low together with increased poverty. Farming systems are changing and fertilizer costs and scarcity make $\mathrm{N}$ fertilizer input inadequate. With changes in climate, herding is becoming a common farming activity with its attendant social-economic problems.

The introduction and use of forage legumes are considered an essential part of the process of intensification (Thomas and Sumberg, 1995) and can improve the influence of livestock on soil fertility when used as livestock feed (Tarawali et al., 2001). In fact, Anon (1997b) believes that the most promising opportunity for integration of crop and livestock is improved animal feeding through dual purpose fallow-forage systems and use of crop residues. During the dry season, when the naturally available feed resources are of very poor quality, herbaceous legumes can also produce substantial quantities of better and nutritious fodder for livestock (Schaaffhausen, 1963; Makenbe et al., 1996; IITA, 1997). Other reports have shown that the inclusion of herbaceous legumes in farming 
systems resulted in increased crop yield, reduced weed infestation and prevented soil degradation (Rattray and Ellis, 1953; Vine, 1953; Tian et al., 1995). Herbaceous legumes have also improved soil physical and chemical properties (Vine, 1953; Lal et al., 1978), and can contribute to the control of Striga hermonthica (IITA, 1997). Central to crop and livestock production, therefore, is the inclusion of herbaceous legumes in the farming systems of the savanna and rainforest agroecologies.

In 2000 and beyond, both the International Institute of Tropical Agriculture (IITA) and International Livestock Research Institute (ILRI) showed interest in the evaluation of lablab in the northern Guinea savanna of Nigeria for its potential contribution to crop-livestock production systems (Ewansiha et al., 2007a,b; 2008; Ewansiha and Chiezey, 2012). Specific activities involved in the lablab research included evaluation of lablab in Samaru in the Nigerian northern Guinea savanna for morpho-phenological variation, potential for crop and livestock production, maize production and drought tolerance. Other experiments involving lablab have also been conducted. In Kano, in the Nigerian Sudan savanna, Ewansiha and Singh (2006) evaluated lablab together with other grain legumes and cereals for drought tolerance. Ewansiha et al. (2012), evaluated lablab for its effects on soil properties and subsequent maizecowpea intercrop in Samaru. The performance of dual-purpose lablab and cowpea was evaluated under maize in Samaru (Ewansiha et al., 2016a).

In Benin City, in the rainforest agro-ecology, experiment was conducted to evaluate lablab together with other herbaceous legumes for their potential use in green-manuring (Ogedegbe et al.,
2016). During the period of evaluation in Samaru and elsewhere, it was observed that lablab suffered from a complex of pests and diseases (Ewansiha et al., 2016b). Despite control using insecticides and fungicides, it was necessary to determine the type of pests associated with lablab. While the results of these various researches have been reported (Ewansiha and Singh, 2006; Ewansiha et al., 2007a,b; Ewansiha et al., 2008; Ewansiha and Chiezey, 2012; Ewansiha et al., 2012; Ewansiha et al., 2016a,b; Ogedegbe et al., 2016), this paper highlights the outcomes of these various researches in terms of production niches for lablab, lablab providing grain and pod for food, lablab as a resource for crop production and for soil protection, and lablab as fodder for livestock production as well as the pests/diseases that affect it.

\section{Production Niches for Lablab}

Forty-six lablab accessions were evaluated and classified (Ewansiha et al., 2007b; Table 1). Of these accessions, six maturity groups were identified: very early (av. 47 days to $50 \%$ flowering), early (av. 54 days), intermediate (av. 72 days), late (av. 98 days), very late (av. 123 days) and extremely late (av. 144 days). The very early, early and intermediate accessions seem suitable for dry savanna with low rainfall or short growing season and the late growing season of the humid forest. These accessions can be grown either as sole crops or in intercrops with cereals. The late, very late and extremely late accessions appear suitable for moist savanna and humid forest with longer growing seasons. These accessions had faster growth and quick soil cover and can therefore provide protection for soils and suppress weeds as well.

Table 1: Classification of lablab purpureus according to time of $50 \%$ flowering

\begin{tabular}{|c|c|c|c|c|c|}
\hline Accession & Maturity group & Days to flowering & Accession & Maturity group & Days to flowering \\
\hline PI555670 & Very early & 42 & TLN6 & Early & 55 \\
\hline PI388019 & Very early & 42 & TLN9 & Early & 55 \\
\hline PI596358 & Very early & 47 & PI388003 & Early & 55 \\
\hline PI392369 & Very early & 47 & PI183451 & Early & 56 \\
\hline PI439586 & Very early & 47 & BARSDI & Early & 58 \\
\hline PI346440 & Very early & 48 & Grif1246 & Early & 58 \\
\hline PI416699 & Very early & 48 & PI532170 & Intermediate & 68 \\
\hline PI388013 & Very early & 48 & PI345608 & Intermediate & 76 \\
\hline PI322531 & Very early & 49 & PI401553 & Late & 91 \\
\hline Grif12293 & Very early & 50 & PI387994 & Late & 95 \\
\hline PI337534 & Early & 51 & Standard1 & Late & 97 \\
\hline Grif969 & Early & 51 & ILRI7279 & Late & 98 \\
\hline PI338341 & Early & 51 & TLN29 & Late & 99 \\
\hline PI388018 & Early & 52 & TLN7 & Late & 105 \\
\hline PI388017 & Early & 52 & NAPRI2 & Very late & 116 \\
\hline PI509114 & Early & 52 & ILRI6930 & Very late & 116 \\
\hline PI288467 & Early & 53 & ILRI4612 & Very late & 123 \\
\hline PI284802 & Early & 53 & PI164302 & Very late & 123 \\
\hline PI388012 & Early & 54 & ILRI730 & Very late & 125 \\
\hline PI288466 & Early & 54 & Standard2 & Very late & 126 \\
\hline PI542609 & Early & 54 & NAPRI3 & Very late & 126 \\
\hline TLN13 & Early & 54 & ILRI7403 & Very late & 129 \\
\hline PI164772 & Early & 55 & PI195851 & Extremely late & 144 \\
\hline
\end{tabular}




\section{Lablab as a Quality Food Crop}

Of the forty six lablab accessions evaluated, fifteen accessions were suitable for vegetable pods, 11 accessions were suitable for grain-type lablab and three accessions were suitable for food-feed use (Ewansiha et al., 2007b; Table 2). With the very early to intermediate accessions, lablab could provide sufficient grain early in the season when food stores would be getting depleted. Grain yield obtained (600-2400 kg ha-1) was comparable with yields obtained with other grain legumes (Ewansiha et al., 2007a; Table 3). The lablab grain had an average protein concentration of $25.3 \%$ which was comparable with protein contents reported for the dry seeds of the common grain legumes (Table 3), indicating the potential for lablab to contribute to high quality grain nutrition. It also reveals the potential of lablab to fix and supply $\mathrm{N}$ since no $\mathrm{N}$ fertilizer was applied. As a grain crop, lablab tolerance to drought ensures that food is available even when rains are erratic and when moisture is limiting. Six accessions were identified to be drought tolerant (Ewansiha and Chiezey, 2012), making it possible to develop drought tolerant varieties through breeding and selection. When various herbaceous legumes and cereals were screened for drought tolerance, the most drought tolerant group comprised of lablab (Ewansiha and Singh, 2006). Lablab is drought tolerant because it has a deep taproot system which can penetrate to more than $2 \mathrm{~m}$ below the soil surface thus enabling it to sustain growth on residual soil moisture (NAS, 1979; Kay, 1979; Duke et al., 1981).

Table 2: Lablab accessions good for vegetable pod, grain and food-feed use

\begin{tabular}{lll}
\hline Vegetable-type & Grain-type & Dual-purpose \\
\hline PI 555670 & Grif 1246 & Grif 1246 \\
PI 439586 & PI 164772 & PI 183451 \\
PI 322531 & PI 183451 & ILRI 4612 \\
Grif 969 & PI 288466 & \\
PI 337534 & PI 288467 & \\
PI 509114 & PI 388003 & \\
BARSD 1 & PI 542609 & \\
PI 345608 & NAPRI 4 & \\
PI 532170 & ILRI 4612 & \\
Grif 1246 & TLN 6 & \\
PI 388019 & TLN 13 & \\
PI 392369 & & \\
Grif 12293 & & \\
PI 416699 & & \\
PI 346440 & & \\
\hline
\end{tabular}

Table 3: Grain yield and mean crude protein (cp) of some dual-purpose legumes

\begin{tabular}{llll}
\hline Crop & Grain yield & $\left(\mathrm{kg} \mathrm{ha}^{-1}\right)$ & $\mathrm{CP}(\%)$ \\
\hline Lablab & $600-2400$ & & 25.3 \\
Cowpea & $200-1400$ & 25.0 \\
Groundnut & $800-2700$ & 25.5 \\
Soybean & $1700-2600$ & 39.0 \\
\hline Source: Ewansiha et al. $(2007 \mathrm{a})$ &
\end{tabular}

Lablab as a Resource for Crop Production

Lablab has a potential for up to an average of 2600 $\mathrm{kg} \mathrm{ha}^{-1}$ of biomass and an average of $64.1 \mathrm{~kg}$ of nitrogen $\mathrm{ha}^{-1}$ (Ewansiha et al., 2007a; Table 4). This means that lablab has high potential for green manure and soil improvement. Moreso, when the biomass is removed as forage to feed livestock, the soil fertility contribution is balanced with the return of the manure and the contribution of the lablab plant roots. With the huge litter of leaves and stems at the end of the growing season which extends into the dry season, high amount of quality crop residue for conservation agriculture is implicated (Fig. 1). In one trial, performance of maize grown following two years of lablab cultivation and incorporation of its plant residues shows that it can support high yield of maize (Ewansiha et al., 2008; Table 5). Lablab fallow supported similar yields of maize across lablab maturity groups from very early to extremely late. Yields of maize for lablab plots were on the average $72.7 \%$ higher than for the natural fallow plots. In another trial, yield of maizecowpea intercrop following one year of lablab fallow and subsequent incorporation of plant residues indicates the ability of lablab to support cereal-legume production systems (Ewansiha et al., 2012; Table 6). Lablab and natural fallows compared well for grain yield and seed weight. Lablab fallow, however, favoured higher fodder yield in maize because it improved the supply of soil organic matter, nitrogen, phosphorus and potassium (Ewansiha et al., 2012; Table 7). Lablab was able to contribute to the observed improvement in soil fertility because it is a nitrogen-fixing crop with remarkable ability to nodulate even without inoculation (NAS, 1979; Duke et al., 1981).

Table 4: Range and mean values of biomass yield and quality of lablab accessions

\begin{tabular}{|c|c|c|c|}
\hline \multirow[b]{2}{*}{ Attribute } & \multicolumn{2}{|c|}{ Range } & \multirow{2}{*}{ Mean } \\
\hline & Min & Max & \\
\hline & & $\mathrm{kg} \mathrm{ha}^{-1}$ & \\
\hline \multicolumn{4}{|l|}{ Root } \\
\hline Biomass & 27.0 & 303.0 & 107.0 \\
\hline Nitrogen & 0.03 & 0.52 & 0.15 \\
\hline \multicolumn{4}{|c|}{ Shoot biomass } \\
\hline Biomass & 453.0 & 7718.0 & 2640.0 \\
\hline Nitrogen & 6.1 & 184.3 & 64.1 \\
\hline
\end{tabular}

Table 5: Grain yield of maize following 2-year lablab cultivation and incorporation of lablab residues

\begin{tabular}{lc}
\hline Lablab accession & Maize yield $\left(\mathrm{kg} \mathrm{ha}^{-1}\right)$ \\
\hline Very early maturing & $5.9 \mathrm{a}$ \\
Early maturing & $6.1 \mathrm{a}$ \\
Intermediate maturing & $6.2 \mathrm{a}$ \\
Late maturing & $6.6 \mathrm{a}$ \\
Very late maturing & $6.5 \mathrm{a}$ \\
Extremely maturing & $6.6 \mathrm{a}$ \\
Natural fallow & $3.7 \mathrm{~b}$ \\
LSD $_{0.05}$ & 0.42 \\
\hline
\end{tabular}




\section{Lablab as Resource for Livestock Production}

Sixteen accessions were of good and high quality forage (Ewansiha et al., 2007a; Table 8). These accessions have potential to improve crop and generate residue, which promises to be the dominant feed resource as crop-livestock integration becomes more developed (Smith et al., 1997). Moreover, the various trials recorded huge litter of lablab, lablab biomass and maize stover which provides opportunity for crop and livestock production through sharing of crop residues. Figure 1 show huge litter of lablab leaves and stems at the end of production period which extends far into the dry season. This means that quality fodder can be available for livestock at a time when fodder becomes scarce, natural grasses become less nutritive and animals lose weight. With a dense growth, the lower leaves are shed, which is a potential crop residue for livestock during growing season. Intercrop of lablab and maize gave good grain and fodder yields of lablab relative to that of cowpea (Ewansiha et al. 2016a, Table 9). Several other experiments have shown the importance of lablab. The vines when cut with sorghum (Sorghum bicolor (L.) Moench) straw gave a mixed fodder of high nutritive values (Shivashankar and Kulkarni, 1989). Selvan et al. (1993) found sorghum-lablab intercrop to be superior in grain yield to sorghumsoyabean intercrop. In Zimbabwe, diets based on maize (Zea mays L.) stover and lablab could provide adequate nutrients to maintain goat productivity during the cropping season (Makenbe et al., 1996).

\section{Lablab as a Resource for Soil Protection}

Evaluation of the performance of six herbaceous legumes in the humid forest region showed that lablab was among the legumes that had the highest soil cover (Ogedegbe et al., 2016; Table 10). Fresh biomass was highest in Mucuna pruriens followed by lablab. This was achieved in eight weeks implying that both legumes can provide soil protection, biomass for green manure or fodder for livestock early in the growing season. Ewansiha et al. (2008) reported that lablab can be a candidate crop for soil protection, green manure and fodder because it has quick growth combined with high biomass production.

Table 6: Grain and fodder yields $\left(\mathrm{kg} \mathrm{ha}^{-1}\right)$ of intercropped maize/cowpea after one-year lablab cultivation and incorporation of lablab residues

\begin{tabular}{lccccc}
\hline \multirow{2}{*}{ Treatment } & \multicolumn{2}{c}{ Maize } & \multicolumn{2}{c}{ Cowpea } & Mean \\
\cline { 2 - 6 } & Grain & Fodder & Grain & Fodder & \\
\hline Lablab & 3400 & 3400 & 400 & 500 & 1900 \\
Natural fallow & 3000 & 2800 & 400 & 600 & 1700 \\
Mean & 3200 & 3100 & 400 & 500 & \\
\hline
\end{tabular}

Table 7: Lablab effects on organic carbon (OC), total nitrogen $(\mathrm{N})$, available phosphorus $(\mathrm{P})$ and exchangeable potassium $(\mathrm{K})$ after one-year fallow

\begin{tabular}{lcccc} 
Treatment & $\begin{array}{c}\mathrm{OC} \\
\left(\mathrm{g} \mathrm{kg}^{-1}\right)\end{array}$ & $\begin{array}{c}\mathrm{N} \\
\left(\mathrm{g} \mathrm{kg}^{-1}\right)\end{array}$ & $\begin{array}{c}\mathrm{P} \\
\left(\mathrm{ug} \mathrm{g}^{-1}\right)\end{array}$ & $\begin{array}{c}\mathrm{K}^{+} \\
\left(\mathrm{cmol} \mathrm{kg}^{-1}\right)\end{array}$ \\
\hline Before lablab & 5.50 & 0.50 & 3.40 & 0.23 \\
After lablab & 5.85 & 0.55 & 5.73 & 0.26 \\
Natural fallow & 5.40 & 0.49 & 3.70 & 0.24 \\
\hline
\end{tabular}

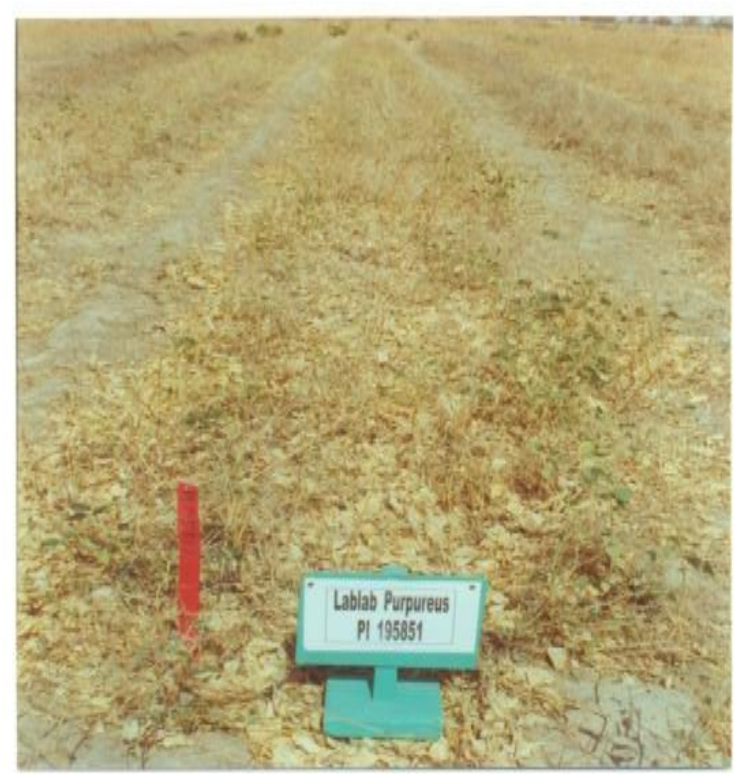

Fig. 1: Lablab litter at end of production period and harvest of pods

Table 8: Leaf dry matter yield and quality of lablab

\begin{tabular}{lcc}
\hline Attribute & Number of accessions & Accession means \\
\hline Fodder t ha $^{-1}$ & 16 & $>1.5-3.1$ \\
& 30 & $<1.5$ \\
Fodder quality $\%$ & & $>20-25.2$ \\
Crude protein & 18 & $<20$ \\
& 28 & $0.17-0.44$ \\
Phosphorus & 46 & \\
\hline
\end{tabular}

Table 9: Grain yield of dual-purpose lablab and cowpea as sole and when grown together with maize

\begin{tabular}{lllll}
\hline Crop variety & Sole & $\begin{array}{l}\text { Early } \\
\text { maize }\end{array}$ & $\begin{array}{l}\text { Late } \\
\text { maize }\end{array}$ & Mean \\
\hline Grain $\left(\mathrm{kg} \mathrm{ha}^{-1}\right)$ & & & & \\
I4612 & 983.4 & 437.3 & 342.6 & $587.8 \mathrm{~b}$ \\
NAPRI2 & 999.5 & 516.0 & 381.8 & $632.4 \mathrm{~b}$ \\
IT89KD-288 & 1240.6 & 638.7 & 527.7 & $802.3 \mathrm{a}$ \\
IT99K-241-2 & 1279.0 & 710.9 & 511.7 & $833.9 \mathrm{a}$ \\
Mean & $1125.6 \mathrm{a}$ & $575.7 \mathrm{~b}$ & $441.0 \mathrm{c}$ & \\
Fodder $\left(\mathrm{kg} \mathrm{ha}^{-1}\right)$ & & & & \\
I4612 & 4407.0 & 2426.6 & 2293.3 & $3042.3 \mathrm{a}$ \\
NAPRI2 & 4192.3 & 2746.0 & 1968.5 & $2968.9 \mathrm{a}$ \\
IT89KD-288 & 2383.5 & 1454.2 & 1550.0 & $1795.9 \mathrm{~b}$ \\
IT99K-241-2 & 2280.3 & 1675.0 & 1220.8 & $1725.4 \mathrm{~b}$ \\
Mean & $3315.8 \mathrm{a}$ & $2075.4 \mathrm{~b}$ & $1758.2 \mathrm{c}$ & \\
\hline
\end{tabular}

Means with similar letter are not significantly different at $5 \%$ level of probability using LSD.

Table 10: Soil cover and yield of herbaceous legumes at 8 weeks after planting

\begin{tabular}{lll}
\hline \multirow{2}{*}{ Legume } & $\begin{array}{c}\text { Soil } \\
\text { cover }\end{array}$ & $\begin{array}{c}\text { Fresh } \\
\text { biomass }\end{array}$ \\
\cline { 2 - 3 }$($ score $)$ & $\left(\mathrm{kg} \mathrm{ha}^{-1}\right)$ \\
\hline Centrosema pascuorum (Mart.) ex Benth & 3 & 240.0 \\
Lablab purpureus (L.) Sweet & 5 & 3210.0 \\
Mucuna pruriens (L.) DC & 5 & 5060.0 \\
Pueraria phaseoloides (Roxb.) Benth. & 3 & 410.0 \\
Stylosanthes hamata (L.) Taubert & 4 & 1070.0 \\
Vigna unguiculata (L.) Walp. & 5 & 1760.0 \\
LSD $_{0.05}$ & 0.36 & 1680.0 \\
\hline
\end{tabular}


Table 11: Pests and diseases observed in Lablab purpureus

\begin{tabular}{llll}
\hline Foliage insects & Pod-sucking insects & Fungal diseases & Parasitic weeds \\
\hline Ootheca mutabilis (Sahlb) & Anoplocnemis curvipes (F.) & Colletotrichum sp. & Cassytha filiformis (Linn.) \\
Ootheca bifrons (Labois) & Cletus notatus (Thumb.) & Curvularia sp. & \\
Podagrica uniforma (Jac.) & Larvae of Helicoverpa armigera (Hbn) & Rhizoctonia sp. & \\
Monolepta goldingi (Bryant) & & Helminthosporium sp. & \\
Monolepta nigeriae (Bryant) & & \\
Lema cephalotes (Lac) & & \\
Leaf miners & & \\
Nematocerus acerbus (Faust) & & \\
Silidieus apicalis (Waterh) & & \\
Aphids & & \\
\hline
\end{tabular}

\section{Constraints of Field Pests in Lablab Production}

A complex of field pests and diseases were observed on lablab. Insect pests and diseases affected the lablab plants right from the planted seeds through the emerging seedlings and vegetative stage to podding. Young millipedes attacked planted seeds and seedlings. The pests and diseases identified included foliage insects, podsucking insects, pod-eating larvae, aphids, fungus and parasitic weed (Ewansiha et al., 2016b; Table 11). Severe damage to pods was caused by the podeating and pod-sucking insects that caused pod filling to fail after attack (Ewansiha et al., 2016b). The pest complex observed on lablab was however, similar to that associated with cowpea. Therefore, as with cowpea, lablab can be successfully grown with adequate use of pesticides.

\section{CONCLUSION}

Lablab, though an underutilized crop, has the potential to serve as a grain, fodder and resource crop in northern and southern Nigeria. Pests can, however, constitute a setback to its production.

\section{ACKNOWLEDGEMENTS}

The authors gratefully acknowledge the institutional support of the International Institute of Tropical Agriculture (IITA) and International Livestock Research Institute (ILRI), the provision of research field by the Institute for Agricultural Research (IAR) and the research support of Prof. U.F. Chiezey, Dr. S.A. Tarawali and Prof. B.B. Singh.

\section{REFERENCES}

Anonymous (1997a). Short fallow systems to arrest resource degradation due to land-use intensification. Project 1 Annual Report 1997. Int Inst. of Trop. Agric. (IITA), Ibadan, Nigeria. $67 \mathrm{pp}$

Anonymous (1997b). Farming systems diversification. Project 10 Annual Report 1997. Int. Inst. of Trop. Agric. (IITA), Ibadan, Nigeria. $67 \mathrm{pp}$

Duke, J.A., Kretschmer, A.E., Jr., Reed, C.F. and Weder, J.K.P. (1981). Lablab purpureus (L.) Sweet. In: Handbook of legumes of world economic importance. Plenum Press, New York. pp.102-106
Ewansiha, S.U. and Singh, B.B. (2006). Relative drought tolerance of important herbaceous legumes and cereals in the moist and semi-arid regions of West Africa. J. Food, Agric. Environment, 4 (2): 188-190

Ewansiha, S.U., Chiezey, U.F., Tarawali, S.A. and Iwuafor, E.N.O. (2007a). Potential of Lablab purpureus accessions for crop-livestock production in the West African savanna. J. Agric. Sci., 145: 229-238

Ewansiha, S.U., Chiezey, U.F., Tarawali, S.A. and Iwuafor, E.N.O. (2007b). Morpho-phenological variation in Lablab purpureus. Tropical Grasslands, 41: 277-284

Ewansiha, S.U., Tarawali, S.A., Odunze, A.C. and Iwuafor, E.N.O. (2008). Potential contribution of lablab residues to maize production in moist savanna of West Africa. J. Sustainable Agric., 32 (3): 393-406

Ewansiha, S.U. and Chiezey, U.F. (2012). Field evaluation of Lablab purpureus (L.) Sweet accessions for drought tolerance in the Nigerian moist savanna. Nigerian J. Life Sci., 2(1): 102-114

Ewansiha, S.U., Ogedegbe, S.A. and Chiezey, U.F. (2012). Lablab effect on soil properties and subsequent maize cowpea intercrop. Agro-Science, 11 (2): 54-61

Ewansiha, S.U., Ogedegbe, S.A. and Chiezey, U.F. (2016a). Relative yields of dual-purpose hyacinth bean and cowpea when intercropped with maize. Legume Perspectives, 13: 35-36

Ewansiha, S.U., Tarawali, S.A. and Chiezey, U.F. (2016b). Observations on pests and diseases in Lablab purpureus in Nigerian northern Guinea savanna. Legume Perspectives, 13: 23-25

Grubben, G.J.H. (1977). Leguminous vegetables. In: Tropical Vegetables and Their Genetic Resources, pp. 70-71

IITA (1997). IITA and ILRI: collaborating for future generations. Annual Report. Int. Inst. of Trop. Agric. (IITA), Ibadan, Nigeria. 96 pp.

Jabbar, M.A. (1995). Energy and the evolution of farming systems: The potential for mixed farming in the moist savannas. In: Kang, B.T., Akobundu, I.O, Manyong, V.M., Carsky, R.J., Sanginga, N. and Kueneman E.A. (eds.). Moist savannas of Africa: potentials and constraints for crop production. Proc. Int. Workshop, Int. Inst. of Trop. Agric., pp. 87-104 
Jagtap, S. and Amissah-Arthur, A. (1999). Stratification and synthesis of crop-livestock production system using GIS. GeoJournal, 47: 573-582.

Kay, D.E. (1979). Crop and product digest No.3-Food Legumes. Tropical Products Inst., London, $435 \mathrm{pp}$.

Kowal, J.M. and Kassam, A.H. (1978). Agricultural Ecology of Savanna. Oxford University Press, London. 403 pp.

Lal R., Wilson, G.F. and Okigbo, B.N. (1978). No-till farming after various grasses and legumes cover crops in tropical Alfisol. I. Crop performance. Field Crops Res., 1: 71-84

Makembe, N.E.T. and Ndlovu, L.R (1996). Dolichos lablab (Lablab purpureus cv. "Rongai") as supplementary feed to maize stover for indigenous female goats in Zimbabwe. Small Ruminant Res., 21: $31-36$

Manyong, V.M., Makinde, K.O., Sanginga, N., Vanlauwe, B. and Diels J. (1997). Farmers' use of organic and inorganic inputs in the northern Guinea savanna of Nigeria. Project 1 Annual Report. Int. Inst. of Trop. Agric. (IITA), Ibadan, Nigeria, pp.5-6

NAS (1979). Lablab bean. In: Tropical Legumes: Resources for the Future. National Academy of Sciences (NAS), Washington DC, pp. 59-67

Ndubuisi, A., Zeddies, J., Manyong, V.M. and Smith, J.W. (1998). Crop-livestock integration along the gradient of resource-use intensification in the northern Guinea savanna of Nigeria. Quarterly $J$. Int. Agric., 37: 105-115

Ogedegbe, S.A., Ewansiha, S.U. and Falodun, E.J. (2016). Relative performance of hyacinth bean and other herbaceous legumes in Nigerian rainforest zone. Legume Perspectives, 13: 33-34

Rattray, A. and Ellis B.S. (1953). Maize and green manuring in south Rhodesia. Rhodesian Agric. J., 40: $189-199$

Schaaffhausen, R.V. (1963). Dolichos lablab or Hyacinth bean: its uses for feed, food and soil improvement. Economic Botany, 17: 146-153

Selvan, S.P. and Gopalaswamy N. (1993). Effect of planting pattern and intercrops in sorghum under dry land conditions. Madras Agric. J., 80: 690-692
Shivashankar, G. and Kulkarni, R.S. (1989). Lablab purpureus (L.) Sweet. In: van der Maesen, L.J.G. and Somaatmadja, S. (eds.). Plant Resources of South-East Asia No 1. Pulses. Pudoc/Prosea, Wageningen, the Netherlands. pp. 48-50

Shivashankar, G., Kulkarni, R.S., Shashidhar, H.E., and Mahishi, D.M. (1993). Improvement of field bean. In: Chadha, K.L. and Kallo, G. (eds.) Advances in Horticulture, New Delhi, India, 5: 277-286

Smith, J.W., Naazie, A., Larbi, A. and Agyemang, K. (1997). Integrated crop-livestock systems in subSaharan Africa: an option or and imperative? Outlook on Agric., 26: 237-246

Tarawali, S.A., Larbi, A., Fernandez-Rivera, S and Bationo, A. (2001). The contribution of livestock to soil fertility. In: Sustaining Soil Fertility in West Africa. Soil Sci. Soc. Am. (SSSA) \& Am. Soc. Agron. SSSA Special Publ., No. 58, pp. 281-303

Thomas, D. and Sumberg, J.E. (1995). A review of the evaluation and use of tropical forage legumes in sub-Saharan Africa. Agric., Ecosys. Environ., 54: 151-163

Tian, G., Kang, B.T., Akobundu, I.O. and Manyong, M. (1995). Food production in the moist savanna of West Africa. In: Kang B.T., Akobundu, I.O., Manyong, V.M., Carsky, R.J., Sanginga, N., and Kueneman E.A. (eds.) Moist savannas of Africa: potentials and constraints for crop production. Proc. Int. Workshop, Int. Inst. of Trop. Agric., pp. 87-104

Vine, H. (1953). Experiments on the maintenance of soil fertility at Ibadan, Nigeria. Empire J. Exp. Agric., 21: $65-85$

Webster, C.C. and Wilson, P.N. (1980). Rain-fed arable farming systems. In: Agriculture in the Tropics. Longman Group Ltd., England. pp. 176-199

Wood, I.M. (1983) Lablab bean (Lablab purpureus) for grain and forage production in the Ord irrigation area. Aust. J. Exp. Agric. Anim. Husb., 2: 162-171

Yamaguchi, M. (1983). Hyacinth bean, Lablab bean, Indian and Egyptian bean; Lablab niger (Lablab vulgaris, Dolichos lablab). In: World Vegetables. pp. $278-279$ 